an elongated alice couverte, nearly due east and west, measuring 35 feet in length. Its sides, about four feet apart, are as nearly as possible parallel, although there are indications of the avenue being narrowed towards its eastern extremity, as we should expect to find. The side blo:ks of stone average from 4 to 5 feet in height, and number eleven on the northern and seven on the southern side, the western end being closed by a fine single siab. The interstices between these blocks are roughly filled up with irregularly shaped smaller stones, evidently built in to prevent the exterior earth and soil of the superimposed tumulus from falling into the sepulchral grotto.

There must have been formerly at least nine cap-stones; of these, two have been removed, as observed above, whilst the whole fabric appears to have been tilted, with an inclination to the south, probably caused either by the unequal pressure of the accumulated sand-drift on the northern side, or by the removal of the ballast from its southern supports. It is difficult to determine whether all the cap-stones are in their original positions, or whether some of them have not slipped between the side blocks from their summits.

Several urns, tulip shaped, \&c., with a cylindrical stone muller, were brought back to Guernsey from this cromlech, and are now deposited in Mr. Lukis's museum.

Not far to the north of this spot is a semicircle of stones, which presents a suspicious appearance.

It is much to be wished that the tenant of this field would prevent the causes of the filthy state in which this cromlech is at present. The stones themselves have not been disturbed since the last exploration.

Entering St. Laurence's parish, to the right of the road, on the hill above the vineries, is La Blanche Pierre, a menhir which is fortunately still preserved. The route is next taken to the north-west, through St. Peter's parish to St. Ouen's, and the small hamlet of Trodais. Here the party visited M. Lefeuvre, who in the course of agricultural operations, has removed a large portion of tumuli on his property, and who, six years ago, found within one of them, and has in his possession, a remarkable cinerary urn with four handles, evidently for suspension. The upper portion of this urn, which is hand-made, not turned, is likewise decorated with an ornamental border, consisting of horizontal lines, so arranged as to form three triangles between each handle. It is of a different and later type than the urns discovered in the cromlechs of these islands. M. Lefeuvre accompanied his visitors to the sites of the tumuli. These curious mounds are in two groups, one group being called Les Hougues de Millais, on one spur of the hills overlooking L'Etac and St. Ouen's bay, to N.W. of La Robeline, and the other on a similar spur to the S.E. of the former, about 800 yards distant, in a line with St. Ouen's windmill; these last are called Les Nonts de Grantez. A portion only of one of the Hougues remains, and exhibits a series of cap-stones, five in number, of which four remain, supported by a dry-walling of smaller slabs, forming a tunnel about i 8 feet long, which lies east and west, and was blocked at either end with a broad stone, of which the west one alone is in situ. It presents an exact parallel to the Creux des Faias, which existed till lately in St. Peter's parish, Guernsey, a few hundred yards west of the menhir at Les Paysans; but which has been swept entirely away. A granite muller was picked up here by the visitors, which also resembled, in a remarkable manner, a similar one picked up but a day or two before by the same gentleman, on the site of the Creux des Faias, in Guernsey, showing an identity of manufacture and a contemporaneity of construction of the tumuli in both islands.

Leaving Les Hougues, and after visiting Les Monts de Grantez, St. Ouen's church, which is being magnificently restored, was examined, and a worked stone of the Neolithic period picked up in the churchyard. Pursuing the circuit of ancient remains, the route descends towards the sea by St. Ouen's pond, where, in the Val de la Mare, St. Peter's parish, are Les Trois Roches, in all probability a portion of a cyclolith. Two only are upright, the third lying prone at a little distance and not visible at first sight, until one approaches close to it. The ground being marshy it has formed a pit for itself. The upright stones have been apparently worked into shape on their summits, whilst their sides are almost polished from cattle rubbing against them. The new road is now traversed through the western portion of St. Brelade's parish, between the dreary dines of Les Quenvais, and ascending by $L a$ Pulente on to the hills of La Moye; a kitchen-midden is to be found at the summit of the ascent, where the soil has been scarped in the formation of the road, a mass of limpet, ormer, mussel, and other shells, at some feet in depth below the surface of the original soil.

The famous menhir of Le Quesnel, which stood so picturesquely to the south of this spot this time last year, has fallen a victim, and in its place a large quarry yawns; but in Le Marais, close by, is a portion of a circle, and an alignement, in connection with the former menhir, is still to be traced. Close to Moye signal staff a natural cropping up of the rock presents a striking resemblance to a cromlech and circle round it. About half a mile from Le Quesnel, and directly above La Corbière Point, is a fine single stone Dolmen called La Table des Marthes, beneath which were found some bronzed implements many years since.

Over the granite quarries of La Fosse Vaurin, is a curious natural work which, aided by the hand of man, presents the appearance of two basins with a channel for emptying one, whilst the fissures to the east resemble a cross, the work, perhaps, of some hermit in medirval times. Several mullers, worked stones, \&c., were found in the locality during this brief visit, and brought back to Mr. Lukis's collection. A seven miles' drive brings one back to St. Helier's. This day's visitation occupied from I I A.M., until 9 P.M., but much time was spent in sketching and measuring, searching for stone implements, \&c. The find for the day was tolerably good, viz.:-Ville Nouaux Cromlech, I; Les Hougues de Millais, I ; St. Ouen's churchyard, $x$; Les Trois Roches, 3; La Moye, 5 stone implements.

40, Hauteville, Guernsey

\section{SOUNDINGS AND DREDGINGS DY THE UNITED STATES COAST SURVEY}

$\mathrm{I}$ the office of the Coast Survey at Washington there are about 9,000 specimens of various kinds of marine animals which were brought up by the sounding lead from the sea-bottom, in the region between the shore of Florida and adjacent States and the outer edge of the Gulf Stream, and descending to a depth of I,500 fathoms nearly. The dredge has been but comparatively little used along the coast of the United States, and that so many specimens were collected by the lead alone is due to the persevering care of the late superintendent of the survey, Prof. A. D. Bache, and to the instructions which he gave to the hydrographical officers. Of course, specimens brought up by the lead can include the smaller animals only, such as Foraminiferæ, Diatomacer, and such like; for the larger animals, the dredge must be employed.

The work thus begun has been resumed by the present superintendent of the Coast Survcy, Prof. B. Peirce. The surveying parties are instructed to take observations of the depth, velocity, and clirection of the Gulf Stream, the temperature and density of the water at different depths, and of the Fauna from the surface down to the bottom. By these researches we may hope that our knowledge of the phenomena of the Gulf Stream will be ilicreased, particularly as regards its powers of transportation from shallow to deeper water, or along its bed, besides its action in forming deposits in particular localities, and its 
possible influence on the growth of coral reefs on its shores.

The first operations under the new direction were carried on between. Key West and Havana, along the route now occupied by a telegraph cable. Dredgings were made at depths varying from 90 to 300 fathoms, and yielded Crustaceans, Annelids, Mollusks, Radiata, Foraminiferæ, Sponges, a single vegetable specimen, being a minute alga, Centroceras clavulatum, and "a number of nodules of a very porous limestone, similar in colour and texture to the limestone forming the range of low hills along the shore of Cuba, but composed apparently of the remains of the same-animals which were found living." Among these Deltocyathus, Caryophyllia, and Pteropods were recognised in the stone, and found in various stages of fossilisation.

At the end of a descriptive list of the specimens collected during the cruise, M. de Pourtales remarks :- "It would be premature to compare this deep-sea Fauna with the animals inhabiting the regions of lesser depth on the coast of Cuba or Florida. In the first place, many of the smaller forms-such, for instance, as the Bryozoa or the Hydroid polyps of those shores-are not yet sufficiently known to enable us to say if any of the species dredged exist in any other than the abyssal region. Then, a very different value must be assigned to the different classes of animals under examination. Thus, the dead shells must be left out of the question, at least the smaller ones, for they may have dropped with the excrement of fishes, or, in the case of Pteropods, have sunk from the surface after the death of the animal. The Crustaceans and Annelids being abundant and generally sedentary, will, when better known, afford good characteristics of the regions of unequal depth. The same remark applies to the sponges and the Foraminiferæ; the great abundance of the latter and the ease with which they can be brought up by the sounding lead render them particularly useful."

From this it will be understood that the United States Coast Survey is in good hands, and may be expected, when the time comes, to take part in the suggested dredging expedition all across the Atlantic, when England and the States, after accomplishing each a half, are to meet and shake hands in mid-ocean.

\section{NOTES}

Professor Henry, the President of the American Academy of Sciences, and Director of the Smithsonian Institution, is now in this country en route to the Continent to attend the meetings of the International Commission on Standards.

WHEN presiding over the distribution of prizes for the Faculty of Arts and Laws at University College, London, on Friday last, the Bishop of Exeter made some admirable remarks on the nature of a true system of education, and of the places which ought to be occupied by classics, mathematics, and natural science, and the proper method of teaching them. In all true teaching a sciêntific method is indispensable; it is because this scientific method has been applied to instruction in Greek and Latin, that such good results have been obtained in this department of education. The introduction of scientific teaching has not hitherto met with the same success because it has not been carried out in the same spirit. In very many instances, those who are endeavouring to promote the study of natural science as a part of education, have made "the great mistake of omitting altogether that which is essential to true study, namely, scientific method. The reason why the teaching of the natural sciences still hangs back in our public schools is, in great measure, the unscientific method in which science has been taught by many. To form a part of real education, the study of science must be pursued in the same rigorous manner as that of classics or mathe- matics; it will then prove as hard work to the learner, and the result of its introduction must be most beneficial. While the exclusive study of mathematics must fail as a complete discipline for the understanding, and the great mathematician may be uncultivated as a man, it is very rarely that you see such a result in the student of exterual nature ; therefore, this study must rank by the side of the other, and must hold a place in no way inferior to it. The practical importance given to these remarks by the experience of Dr. Temple at Rugby, ought to make them carry great weight with all teachers of science.

Dr. Henrici has been elected by the Council of University College, London, Professor of Mathematics, in the place of Dr. Hirst, who resigned the professorship, on his appointment to the Assistant-Registrarship of the University of London. Dr. Henrici had acted as Prof. Hirst's assistant during the whole of the session just ended. He had pursued his mathematical studies at Carlsruhe under Professor Clebsch, and subsequently at Heidelberg, where he attended Prof. Hesse's lectures on mathematics, and those by Prof. Kirchhoff on theoretical physics. While at Heidelberg he took his degree of Doctor of Philosophy in the highest grade, and the Philosophical Faculty of the University considered the dissertation which he wrote on that occasion to have so high a scientific value, that they recommended the government of Baden to recognise its importance by conferring upon Dr. Henrici a special public distinction. Dr. Henrici subsequently prosecuted his studies at Berlin and Kiel, and then came to England, where he has resided nearly five years.

THE completion of the deep-sea cable between Falmouth and Bombay was celebrated last Thursday evening by an entertainment given by Mr. Pender, chairman of the British-Indian Submarine Telegraph Company, at which royalty largely assisted. Complimentary messages were exchanged between the Viceroy of India and the President of the United States, the distance of 8,442 miles being accomplished in forty minutes; between the Prince of Wales and the Khédive, the Prince of Wales and the King of Portugal, the Prince of Wales and the President of the United States, and the Prince of Wales and the Viceroy of India. This is the first instance of direct telegraphic communication between India and America. The comic side of telegraphic communication was presented by the message between the Prince of Wales and the Viceroy, which, though despatched soon after twelve at night, and only nine minutes on its way, reached Lord Mayo at five in the morning, when his lordship was, naturally enough, fast asleep. What will be the result when the earth is completely girded with a telegraphic cable, and a message is sent to the antipodes? The question between night and day will be expanded to one between to-day and tomorrow, to say nothing of yesterday.

THE Royal Commission on Scientific Instruction and the Adancement of Science has held two meetings since our last issue.

THERE will be an election at Magdalen College, Oxford, in October next, to six Demyships and one Exhibition. Of the Demyships, one will be mathematical, one in natural science, four classical. The Exhibition will be in natural science. It is necessary that candidates for the exhibition should prove to the satisfaction of the electors that they cannot be supported at college without such assistance. Evidence on this point will be considered as confidential. No person will be eligible for the Demyships who shall have attained the age of twenty years, and (in the case of candidates in mathematics and natural science) who is not sufficiently instructed in other subjects to matriculate as a member of the college. The stipend of the above Demyships and Exhibition is 75l. per annum, inciusive of all allow. 